\title{
Political Accountability and Television Media
}

\author{
Syaiful Halim \\ Fakultas Ilmu Komunikasi Universitas Esa Unggul Jakarta, INDONESIA \\ Author email: syaifulhalim@yahoo.com
}

Published: 7 September 2018

\begin{abstract}
In the fast development of social reality like right now, it is possible for media to have greater role. Media are not only the channel that transmits information throughout the world but also media are the medium to design agenda and notify humans important things so that it becomes materials for interaction in other communication channels. Mass media have systematic influence in the political system and public policy. The political accountability is opportunity for politicians to making responsible for their activities and all issues before their audience whether they is part of their constituents or not. Therefore, impression management style (the techniques used by actors to develop some impressions in certain circumstances for some goal achievements) like proposed by Erving Goffman in his dramaturgy theory. There are many examples described on the stuttering attitude of politicians' political accountability in this country. Recently there are some tendencies among the media owners to embrace "some political party cadres" to occupy the important positions in the media from members of the board of editors to the position of chief editors. With the naked eye, it may be really meant as efforts of building political power for the related media if compared to to the achievement of media professionalism.
\end{abstract}

Keywords: politic; mass media; political communication; accountability; television

eISSN: 2550-214X (C) 2018. The Authors. Published for Idealogy Journal of Arts and Social Science by UiTM Press. This is an Open Access article distributed under the terms of the Creative Commons Attribution-NonCommercial-NoDerivatives License (http://creativecommons.org/licenses/by-nc-nd/4.0/), which permits non-commercial re-use, distribution, and reproduction in any medium, provided the original work is properly cited, and is not altered, transformed, or built upon in any way.

\section{INTRODUCTION}

When globalization ties humans in the narrower circumstances, media are admitted to become main demand. Whoever the individuals are, from whatever families or tribes and regions and countries or continents they come from, they are here in this century, i.e., the century of media. In this century humans depends their life on media (Halim, 2009, p. 3). Sophisticated communication technology has created what Emil Dovifat called "the global public" or "Weltoffentlichkeit".

Since 1964 mass communication has reached a global audience directly and simultaneously. Via communication satellite, humans are able to see one picture or listen one sound to three billion people throughout the world simultaneously. What communicators only do is, i.e connecting to the transmitter apparatus and on the contrary, what million people only do is, i.e., turning on the receiver apparatus (Rakhmat, 2005, p. 186).

When The Twin Towers of WTC in the USA were hit by terrorist planes (as reported by the international media), the world witnessed terrible but annoying drama for the Super Power simultaneously. Audience all over the world witnessed the seconds of the tragedy: the planes approached the twin towers, hit the buildings, the buildings exploded and destroyed, and mass were ini panic. US President George Walter Bush pretended to be calm by reading a story in front of pupils and other dramas. The range of time between the events and media distribution to audience is not again hours or days but minutes or seconds to calculate time. It is the meaning of actuality for media particularly television. In this matter, it presents pictures and sound containing the reality immediately.

Speed and "reality"-ness shown from the pictures and sound were witnessed by hundreds of million people all over the world so that it planted an image of terrorists with all effects of destruction, panicky 
and tension which occur. "The media globalization has made various terrors as global spectacle which creates global thinking, perception and consciousness," Yasraf Amir Piliang told, to define the understanding on the post terror or the critics on the influence of media distribution concerning the terrors (Piliang, 2010, p. 129).

See the model of post-terror via media as follows:

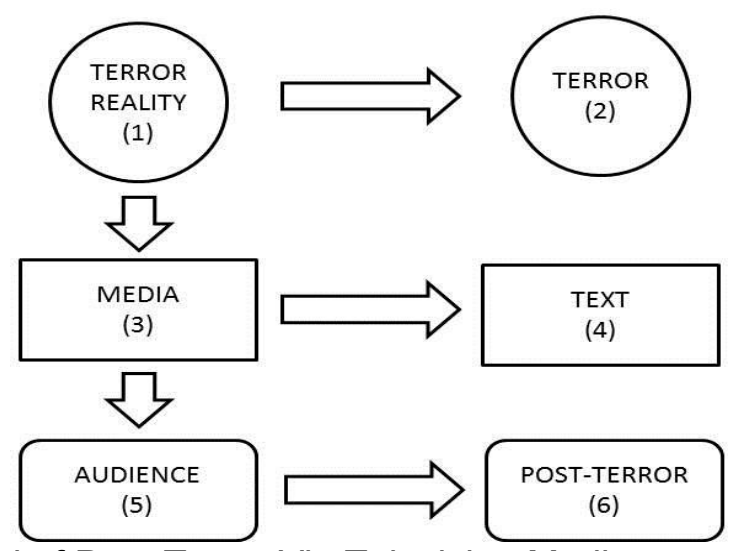

Figure 1: Model of Post-Terror Via Television Media

Reading the above model is that the terror reality (1) has the effects of destruction, panicky dan tension to people who live in the event location and its surroundings where the terror occurs (2). The terror reality is constructed and distributed by media (3) in various kinds of text (4), including images and sound to audiences (5). The media globalization transmits the effects of destruction, panicky and tension from people who live in the event location to the audiences' rooms and houses all over the world in a kind of the post-terror (6).

Technology makes media workers easier because they are not necessary to bring big and heavy work equipment that spends a lot of time. With satellite news gathering (SNG) portable which has a baggage size, television journalists can directly transmit rushes copy and master edit to the broadcasting centre and they retransmit it to houses. Technology makes all obstacles solved. It makes audience capable to receive media message immediately. It becomes reference. They discuss it and they give response to whatever they think. Therefore, the media globalization goes perfectly.

"The television power bases on massiveness, simultaneity, and charm images and broad range. If compared to other media, television is easy to be consumed/watched because audience only turns on and selects channels, so it can present directly into the houses and Indonesia's households watch it enjoyable," Idi Subandy Ibrahim told when he connects between television technology power and its broad range capability to reach people throughout the Archipelago (Ibrahim, 2011, p. 87).

The importance of media for this short life is not only because humans need the supply of knowledge and vision but also media become soul mate and life support to decide social behavior and attitude. Moreover, media also become guidance like the holy books with "preachers" who frequently preach inside the box. As McLuhan states, media are like the prolongation of our senses, organs and nerves. Moreover, it becomes our world narrower and narrower. The power of mass media has transformed to "religion" and secular "gods". It means that human's behavior does not base on traditional religions but we have been unconsciously under the governance of mass media like television programs (Cavallaro, 2004, p. 365). 
"The simulation era or simulacra," French Philosopher Jean Baudrillard said when he adopted the concept from Plato who said on the relationship between the real and the copy hundreds of years ago. Concerning the post terror, Baudrillard states that in The Transparency of Evil: Essays on Exreme Phenomena (1993: 75), current violence, the violence produced by our hyper-modernity is terror. "The simulacrum of violence appears from behind the screen than the bottom of our desire: the violence inside the universe of images," he said (Cavallaro, 2004, p. 365).

In conclusion, in the fast development of social reality like right now, it is possible for media to have greater role. Media are not only the channel that transmits information throughout the world but also media are the medium to design agenda and notify humans important things so that it becomes materials for interaction in other communication channels.

The assumption of the vital demand becomes main capital for the media workers to begin their activities as press institution. They frequenly convey the perspective in various occassions, so all workers design and produce such a message appropriate to the audiences' desire.

Media exist because public needs their existence. The most important thing is that media deliver whatever public needs while public will keep watching. The assumption of "audiences' desire" and

"whatever public needs" is the camouflage for the ideology of the media workers as well as the extension of the media owners.

In this context, the assumption of McLuhan that the important thing for mass communication is the media itself (Littlejohn, 2009, p. 405), is definitely acceptable. The media message is identic to the media that transmit it. Audiences suddently become prisoners who are completely prepared to receive whatever injection to their bodies as long as they can keep healthy. The truth of the hypodermic theory or the stimulus response theory is proved and these remain relevant in this century. The assumption means that audiences never question the honorable values of the media.

\section{LITERATURE REVIEW}

Mass media have systematic influence in the political system and public policy. So, according to David Stromberg, politicians tend to support the information of voters and they cover issues in favour of the voters' interests. Politicians carry out it because it is not only directed to the voters who have full of information to vote but also the voters who have lack of information. In the assumption, the two typologies of the voters will vote the candidates who want to fight for their interests.

Delli Carpini and Keeter (1996) uncover that in the US presidential election in 1988, nine of 10 voters are among the most knowledgeable people. Moreover, Stein and Bickers (1994) state that people with general knowledge may be more possible to consider new projects in their region. Moreover, the conscious voters concerning new projets feel obligated to vote their representatives (Stromberg, 2002, pp. 95-106).

In the simpler language, there is tight inter-relationships between media and politicians. They will participate to "serve" media in the information supply in relation to audiences because it is based on their willingness to "take" close to their constituents. Meaning behind the political activities is political accountability or the responsibility to the political activities of politicians before their constituents. And media make the activities distributed broadly and fast. Therefore, Stromberg believes that mass media has systematic influence in the political system - exactly the same as the communication of political marketing. 
To read deeper in the meaning behind the imagery with the label of political accountability, the writer will describe some aspects of media in the context of political communication. According to Harsono Suwandi in the foreword of a book with the title of Konstruksi Realitas Politik dalam Media Massa: Sebuah Studi Critical Discourse Analysis Terhadap Berita-berita Politik, media has important role in political communication activities concerning the following aspects of:

1. The broad coverage in the transmission of political information; being able to break through borderline (geography), group of age, gender and socioeconomic status (demography) and difference of ideology and orientation (psychography).

2. The capability for multiplying message appropriate to amount of printing exemplars or broadcasting repetition.

3. The capability for making the discourse of political issues appropriate to editorial policy which determines the presentation of news content to be reported.

4. Through the function of agenda setting, media have very great opportunity to report a political event until it becomes public agenda.

5. The news coverage of a political event usually relates to other media until it establishes a chain of information (media as link in other chains) (Hamad, 2004, pp. xv-xvi).

The explanation of Brian McNair in his book, An Introduction to Political Communication (1995: 2-15), "In the mediation era, the function of mass media in political communication can become transmitters of political message from parties outside themselves as well as become senders of political message constructed by journalists to audiences."

Moreover, Harsono Suwandi states as political agents, media carry out the framing of political messages and the process truly results in an event or a political actor to having certain images. In the framing of political messages, media can select facts which will (and will not) be entered into the text of political news. Furthermore, in making political news, media can select political symbols or labels as well. These are the two phases plus the uploading in media which finally determines images constructed in audiences' mind concerning a power or a political actor (Hamad, 2004, pp. xvi-xvii).

Therefore, in the middle of the atmosphere of complicated technology and information overload, media become vital need in the concepts of political marketing communication. And definitely among attacks to media political economy system with full of capitalist content, media truly provide enough broad room for politicians to carry out the function of their political accountability.

"When entering the elements of capitalism, mass media should inevitably think of market for earning revenue in either sales or advertising. It also occurs in the presentation of political events for the capital influence, the mass media will focus more on the satisfaction of audiences (customers and advertisers) as market in the consumption of political news," Ibnu Hamad said (Hamad, 2004, pp. xvi- xvii).

It means that the celebration splendour of commodification shown in various news programs with news themes of lightweight, entertainment and definitely commodity is not truly the standards or the program genre. The commodification pressure is very possible that the news programs do not have identity and go with the flow of text consumption - as described by Norman Fairclough in his communicative event model uncovering micro, meso and macro phase in the critical discourse analysis (Fairclough, 1995, p. 288).

Commodification is a keyword stated by Karl Marx as "ideology" dwelling behind media. According to Marx, the word can be meant as efforts to put forward earnings if compared to other goals (Burton, 2008, p. 198).

Baram and Davis explain commodification as the transformation process of life value to becoming the exchange values alias commodity. "The commodity fetishism makes public interrelated as fetish "attaches the commodity fetishism into labour products because they are commodity products. Therefore, the commodification process defines the transformation process to applying life values used by humans - becoming the exchangeable value, like the exchange value of US dolar currency. When 
transforming the product values determined on the basis of their capability to meet individual and social demand for the saleable products in market, commodification removes products from the more meaningful social context to be something more beneficial in the aspect of business and the ideology of 'free market' value," they told (Burton, 2008, p. 2).

Back to the problem. Read the opinion of Dan Nimmo as well. Dan Nimmo in his book, Political Communication and Public Opinion in America (1978: 185-186) divides the political events into four types: routine, incidental, scandal and unintentional events. "The four events can always become the interesting news material. It is because a routine event can involve a famous political actor so that it can become news; the incidental event like road traffic accident experienced by one political actor will become news as well. The scandal that a political actor did is also hot news.

Reporters frequently get political information unintentionally among others because as the news source, political actors camouflage it and then in fact it becomes big news," he said (Burton, 2008, p. 2).

It means that there are four gaps which can be "passed" through by politicians to appear in media at no cost. These include a scandal they undergo. See the model of the political accountability via media as follows:

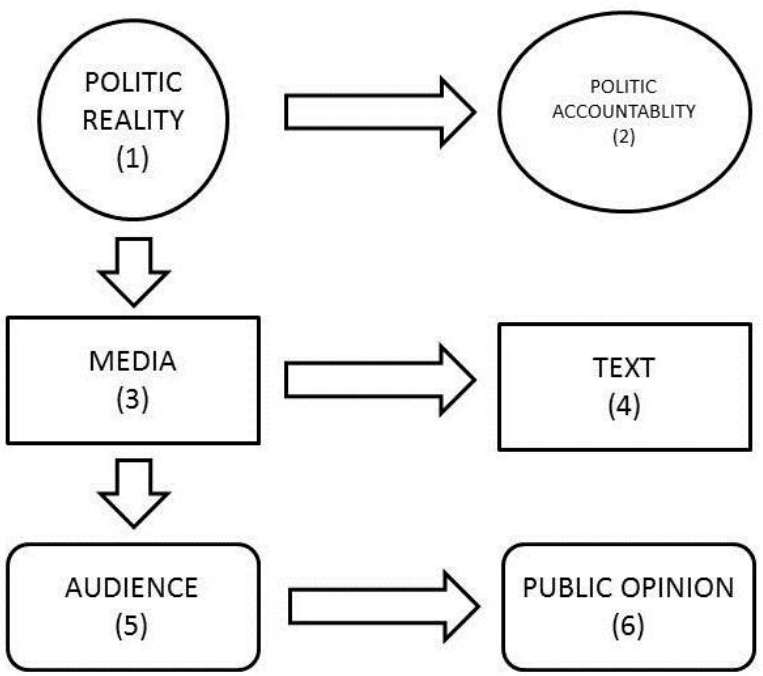

Figure 2: Model of Political Accountability Via Television Media

The political reality (1) will run itself and it can be sensed by media workers, then it will be constructed according to media perspective (2) to become a text (3). In the next phase, the media will distribute the text to audience (4). In the audience's mind, the text will develop and become discussion material so that it becomes public opinion (5) positively or negatively. However, for politicians the positive or negative effect has to be answered immediately as political accountability (6). Finally, the political accountability becomes part of the political reality which will be observed and become the media agenda.

The political accountability is opportunity for politicians to making responsible for their activities and all issues before their audience whether they is part of their constituents or not. Therefore, impression management style (the techniques used by actors to develop some impressions in certain circumstances for some goal achievements) like proposed by Erving Goffman in his dramaturgy theory (Kuswarno, 2009, p. 116). Coat or blazer should be always worn wherever they are and in whatever circumstances. Moreover, it occurs particularly when camera directs to their faces.

Manohara Odelio Pinot (the Indonesian celebrity, the former wife of a nobleman from a neighboring country) or singer Syahrini (the Indonesian celebrity) are the almost perfect "examples" to mention 
celebrities who are "smart" to play their impression management style and "their celebrity accountability" on glass screen. They are always calm, confident, smart to play their drama and "very conscious" in front of camera - the understanding has to maintain their appearance at their front stage every time camera direct to their face. For the two celebrities, conflict and negative issues are definitely read as opportunity to put the issues from their version, self-defence, counter response as well as existence in the sector of entertainment.

Moreover, Manohara should get plus points for "her success" to subdue the media might. Perhaps the beautiful model should thank to "the guidance" of her marriage when she was under age, the alleged domestic violence from her husband, i.e., Prince Kelantan and all dramas binding her life. Therefore, television workers are admired and care, then they distribute her life to television audience.

Manohara's glamour and Daisy Fajarina's proficiency as her "campaign manager" are truly very amazing. As if they have extraordinary charisma, so they are able to enter into personal domain in the audience's mind. During the fever time of Manohara's conflicts, they almost do not give opportunity for audience's eyes to watch other issues. They are also very proficient to creating one drama to another one so that television broadcasting stations have desired to cover her life. However, observe the accountability "style" of Democratic Party politician Angelina Sondakh. She had been given great "stage" by media before she stood in "Broadway" Senayan. Definitely since she was elected as Putri Indonesia (Miss Indonesia). However, as far as eyes can see and ears can hear, she almost never uttered the astonishing ideas on her political vision during her activities at the political stage. Furthermore, when her name was mentioned in the bribery case of Sesmenpora (Secretary of Minister of Youth and Sports).

She frequently talked about her sorrowness as usual after her husband - actor and Democratic Party politician Adji Massaid - passed away. On the contrary, she almost hardly answered all questions from reporters on the issue straightforwardly. In fact, media workers as the ambassador of audience really expected "her intelligence" to mention whatever points concerning the bribery case. Media did not wait the sad stories after she has to be a single parent.

Later she was definitely known as the corruption case suspect until she had to be put behind the bars. Her famous name as former Miss Indonesia and politician was sunk and her status changed. Right now, public mostly knows her as the corruption case detainee. The similar cases are also experienced by Anas Urbaningrum, Andi Malarangeng, Nazaruddin as well as other corruption case detainees.

There are many examples described on the stuttering attitude of politicians' political accountability in this country. They are not only from celebrities but also from all social classes in Indonesia. Family members or close friends of the famous politicians who luckily have position in Senayan or in Regional House of Representatives (DPRD) in wherever region become part of the long list. Moreover, if there is rather "speaking", it tends not to be too aggressive to embrace media. The "aggressive" word should not be meant spirit to persuade media personally but also to throw a discourse.

In the different "class", we also can observe the political accountability "style" of the high-class politicians in this country. Megawati Soekarnoputri with her Indonesia Democratic Party of Struggle (PDIP) always appears with the image of "mother'"s grassroot people. Along with the image, she always becomes the moorings of grassroot people and the attention of tens of camera as well. The reporters' microphone frequently appears in front of her face. The power as "mother" is frequently more prominent if compared to other imageries. However, "the disease" to raising certain reactions for her dislikeness to one issue never disappears.

After she was inaugurated as president to replacing Indonesian President KH Abdurrahman Wahid, she was lazier than before to talk and see her "motherhood" in front of camera. Therefore, reporters tend to search information and her statements in her speech or the close people around her. Out of her closed attitude and "innocence" to raising her reaction, her statements are difficult enough to get it "twisted" as news. 
Before occupying the position of Indonesia's Coordinating Minister of Political, Social and Security Affairs, Susilo Bambang Yudhoyono (SBY) was infrequently included as a newsmaker. However, he was known to speak fluently and deliver facts in front of camera. Whatever hard or critical questions were usually able to be defeated when he gave answers in detail. He tended to talk in long, regular and systematic sentences with clear articulation and stable sound rhythm. He was not temperament and easy to raise his sound intonation.

When occupying the position of Indonesia's Coordinating Minister of Political, Social and Security Affairs, he talked much in formal circumstances. In this meaning, he truly liked to talk in a kind of press conference if compared to doorstop. And if he should explain it in doorstop, he usually gave the explanation of material directly without any question asked by the reporters. The explanation was given after his aides reported issues that the reporters wanted to search.

After he was inaugurated as Indonesian president in fact SBY became very close to reporters. He was actually more comfortable to talk whatever issues he had in mind and answer whatever questions given as well as wherever location he was. In this matter, the important quotations should not be obtained from his speeches but the sources of data can be obtained in all circumstances and events.

Muhammad Jusuf Kalla (JK) is businessman, politician and state official who is usually close to mass media. He can be "pointed" wherever and whenever he meets reporters as well as whatever questions to be asked. He also tends to have excellent self-control and indirectly get angry when he is asked questions which do not sit well in his heart. When occupying the position of Indonesia' Coordinating Minister for People's Welfare, many reporters hunted new issues from JK. Moreover, they were never reluctant to knock his office door. He was not parsimonious to give his time and opinion. The weakness of unclear accent and articulation gets in balance to his hospitality.

After he is appointed as president, JK still appears with himself. He remains easy to be pushed with mike and he answers the reporters' questions. For his openness, he definitely builds controversy and polemics particularly his insynchronization with SBY.

Out of media demand requiring to search important information from sources and demanding politicians ready to show their political accountability, it is not secret again that there are many politicians who have close relations with media workers in field.

Some politicians from the leading political parties who right now occupy some important positions generally build good relations with journalists in field in the long period of time. The close relationship factor frequently makes them chosen as the regular new sources to give doorstop statements or invited to studio plus pushing aside smart politicians but being reluctant to make close relations with media workers.

Herman, Edward S, and Noam Chomsky in their book, Manufacturing Consent, The Political Economy of The Mass Media explain other gaps to "play" in media - in the context of glass screen. "The first filter for the US mass media in the manufacturing consent to the opinion which wants to be developed (propaganda) is size, the ownership and the market orientation of the media. The second and next filter is advertising, sources, weapon and laws, and anti-communism as well," they said (Kuswarno, 2009, p. 116).

Capitalism provides very broad room for capital owners to totally control their media. The points that make them melted in front of anyone including politicians are the ownership, market orientation and advertising. The support to perpetuating the ownership and freedom of carrying out the media in secure political context for media business is the most attractive offer.

The media owners is truly desire to secure their market orientation and advertising cakes. Therefore, basically the implementation of Broadcasting Laws seriously become the scariest threat to the media owners and make them very open to politicians (particularly from the governing political parties with their policy making in the broadcasting sector. 
Observe the following model of reality construction in television media! It describes a variety of gaps for politicians to approach media workers from those who have the status of journalists, programmers, marketing staff to the media owners. See the model of reality construction in television media as follows:

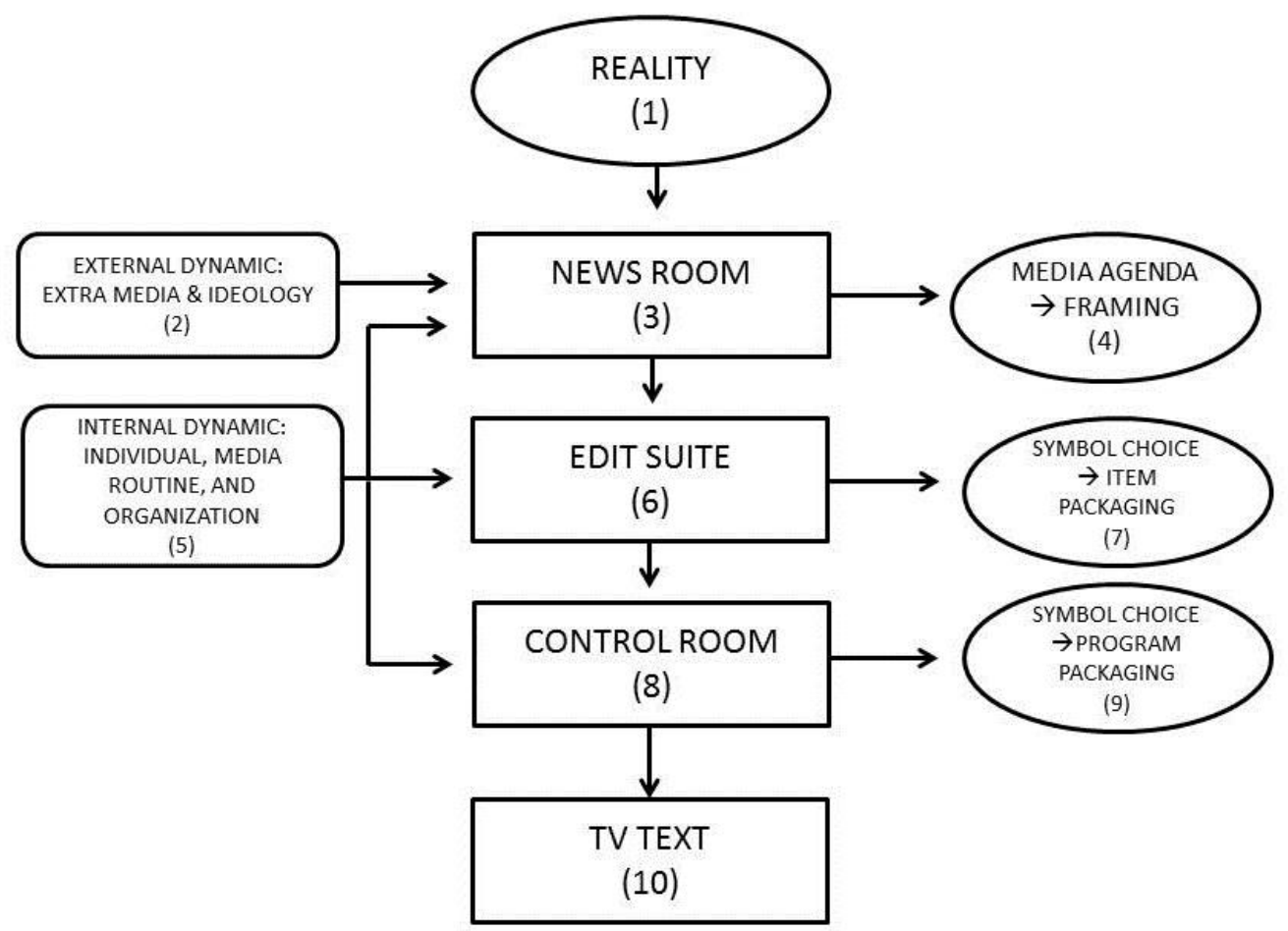

Figure 3: Model of Reality Construction in Television Media

The model simplifies the flow of television text production, and it starts from reality (1) which becomes the attention of journalists in the board of editors (4) to process as media agenda and frame it as news (5). As discussed by scholars of the critical theory, the board of editors is not neutral room with free of interest. In the middle of capitalism, the room gets "perfect pressure" externally (2) covering the dimension of extra media and ideology as well as internally (3) covering the dimension of individuals, media routinely, and the organization. The dimensions in the external and internal domain have been adopted from the hierarchy of influence model by Pamela J. Shoemaker and Stephen D. Reese (Sobur, 2009, p. 138).

The hierarchy of influence model from Pamela J. Shoemaker and Stephen D. Reese does not only occur in the board of editors but also enter into the editing room (6) until influencing the symbol selection and the item packaging (7). And the influence also breaks into the control room (8) which has interests of entering other symbols and making it the program packaging (9), and until it is broadcasted as television text (10).

As the statement of Herman, Edward S, and Noam Chomsky, the gaps are not directly to the board of editors but can be through extra media, the organization and individuals in the board. Each dimension gives "opportunity" to be approached with various ways as well. However, as described at above on the closeness of journalists in field with politicians, according to the writer, it becomes the definitely possible gap which politicians can "play".

Therefore, we can imagine if the owners' television broadcasting stations are involved in political arena as well. Moreover, if they are part of the media conglomeration in this country. The unstopped promotion and campaign, unlimited image campaign and persuasion to their political vision or the vision of their political parties have been definitely uncontrollable. 


\section{RESULTS AND DISCUSSION}

The success of Golkar Party gots $24,480,757$ votes (21.58 percent) and the number occupied it as the winning political party passing through Indonesia Democratic Party of Struggle (PDIP) in the 2014 legislative general election it had close relations to media role. Politics in the simulation era relates to image making. Through glass screen, radio bradcasting and newspaper pages, images can be created and inserted into public collective mind (Luwarso, 2004, pp. 1-2).

Television is the funnel for the dominant groups. And we can say here that most of television broadcasting stations in this country have emotional intimacy with Golkar Party (Luwarso, 2004, p. 4). Therefore, in the 2009 General Election - and even before the 2014 General Election - political parties had great motivation to control television media. Golkar Party remains occuping the leading row in this matter and the biggest stakeholder is in the hand of Golkar Party Chairman Aburizal Bakrie particularly in TVOne and ANTV.

Moreover, it is not secret again if other broadcasting stations - instead of MetroTV being under the mass organization of Nasional Demokrat - has close relation with prominent Golkar Party leaders. However, "the struggle" of President Susilo Bambang Yudhono and the highest leaders of Democratic Party to embrace television media cannot be abandoned as well.

SBY has extraordinary experience on "the sweet media support" to the pataphysics efforts - the borrowed word from Yasraf Amir Piliang on the imagery - when he feels humiliated by President Megawati Soekarnoputri. In fact, previously SBY had made a move with the social service advertising on the general election security under "the executive producer" of Office of Coordinating Minister for Political, Social and Security Affairs (Luwarso, 2004, p. 8). Therefore, through the actors of "political characters" in Democratic Party and chatting actions, SBY truly keeps controlling and increasing his image performance in public eye and before his constituents in utilizing media - without any embarrassment to act as political agent. And SBY is definitely conscious to "play" his political accountability style in media whenever they are particularly on glass screen.

After he does not occupy again as Indonesia president, SBY is also active to build imagery through social media. We should remember when his name is called in the religion blasphemy case trial with the suspect of former Greater Jakarta Governor Basuki Tjahaja Purnama. Then, he directly invited the media and he gave explanation in detail concerning his position in this case. The political accountability step has been being played in joy and happiness.

Recently there are some tendencies among the media owners to embrace "some political party cadres" to occupy the important positions in the media from members of the board of editors to the position of chief editors. With the naked eye, it may be really meant as efforts of building political power for the related media if compared to the achievement of media professionalism. The assumption for the suspicion is very simple concerning competency. And the trend can become the evidence on gaps that politicians enter into the board of editors as described in the model of reality construction in television media.

\section{CONCLUSION}

Epilogue that should be stated over all discussions is the black hole issue opened great for politicians in this country to celebrate political accountability on glass screen. Television media truly provide broad room - among the commodification of desire - to enter whatever things through either news, infotainment or entertainment programs. The broad room should be read as "gap" which is definitely possible to be used by politicians to optimally play all of their impression management in television. Yes, it is on behalf of political accountability or political marketing communication. 
On the contrary, from the different perspective what about the position of audience? Once again, we have to admit that audience is the most disadvantage party to the circumstances. Remember! We should return back to the aforesaid description on the owners of television broadcasting stations who participate in political arena as well. Moreover, they are part of media conglomeration in this country. In the writer's opinion, the costs that have to be paid behind the political game of the politicians on glass screen are very expensive.

* This article was presented at AICAD, 1st Asia International Conference of Art \& Design in Bandung, West Java, Indonesia, on October 2-3, 2017.

\section{REFERENCES}

Kritis dan Cultural Studies. Yogyakarta: Jalasutra.

(2013). Postkomodifikasi Media: Analisis Media Televisi dengan Teori

Analisis Semiotik, dan Analisis Framing. Bandung. Remaja Rosdakarya.

Burton, Graeme. (2008). Pengantar untuk Memahami Media dan Budaya Populer.

Cavallaro, Dani. (2004). Critical and Cultural Theory: Teori Kritis dan Teori Budaya. Yogyakarta:

Penerbit Niagara.

Fairclough, Norman. (1995). Media Discourse. London: Edward Arnold.

Halim, Syaiful. (2009). Gado-Gado Sang Jurnalis: Rundown Wartawan Ecek-Ecek. Yogyakarta:

Jalasutra.

Hamad, Ibnu. (2004). Konstruksi Realitas Politik dalam Media Massa: Sebuah Studi Critical Discourse Analysis terhadap Berita-berita Politik. Jakarta: Granit.

Ibrahim, Idi Subandy. (2011). Kritik Budaya Komunikasi; Budaya, Media dan Gaya Hidup dalam Proses Demokratisasi di Indonesia. Yogyakarta: Jalasutra. Jakarta: Gramata Publishing.

Kuswarno, Engkus. (2009). Metodologi Penelitian Komunikasi Fenomenologi: Konsepsi, Pedoman, dan Contoh Penelitiannya. Bandung: Widya Padjadjaran.

Littlejohn, Stephen W. dan Foss, Karen A. (2009). Teori Komunikasi: Theories of Human Communication. Jakarta: Penerbit Salemba Humanika.

Luwarso, Lukas (ed). (2004). Media dan Pemilu 2004. Jakarta: SEAPA.

Piliang, Yasraf Amir. (2010). Post-Realitas: Realitas Kebudayaan dalam Era Post- Metafisika. Yogyakarta: Jalasutra.

Rakhmat, Jalaluddin. (2005). Psikologi Komunikasi. Bandung: Remaja Rosdakarya. Sobur, Alex. (2009). Analisis Teks Media: Suatu Pengantar untuk Analisis Wacana,

Stromberg, David. (2002). Distributing News and Political Influence dalam The Right to Tell: The Role of Mass Media in Economic Development. Washinton DC: The World Bank. 